\title{
The F-actin cytoskeleton in syncytia from non-clonal progenitor cells
}

\author{
Bartosz Jan Plachno • Piotr Świątek • \\ Malgorzata Kozieradzka-Kiszkurno
}

Received: 2 July 2010 /Accepted: 1 September 2010 / Published online: 28 September 2010

(C) The Author(s) 2010. This article is published with open access at Springerlink.com

\begin{abstract}
The actin cytoskeleton of plant syncytia (a multinucleate cell arising through fusion) is poorly known: to date, there have only been reports about F-actin organization in plant syncytia induced by parasitic nematodes. To broaden knowledge regarding this issue, we analyzed $\mathrm{F}$-actin organization in special heterokaryotic Utricularia syncytia, which arise from maternal sporophytic tissues and endosperm haustoria. In contrast to plant syncytia induced by parasitic nematodes, the syncytia of Utricularia have an extensive Factin network. Abundant F-actin cytoskeleton occurs both in the region where cell walls are digested and the protoplast of nutritive tissue cells fuse with the syncytium and also near a giant amoeboid in the shape nuclei in the central part of the syncytium. An explanation for the presence of an extensive F-actin network and especially F-actin bundles in the syncytia is probably that it is involved in the movement of nuclei and other organelles and also the transport of nutrients in these physiological activity organs which are necessary for
\end{abstract}

Handling Editor: Pavla Binarova

B. J. Płachno $(\square)$

Department of Plant Cytology and Embryology,

Jagiellonian University,

52 Grodzka St.,

31-044 Cracow, Poland

e-mail: bartek78pl@poczta.onet.pl

P. Świątek

Department of Animal Histology and Embryology,

University of Silesia,

9 Bankowa St.,

40-007 Katowice, Poland

M. Kozieradzka-Kiszkurno

Department of Plant Cytology and Embryology,

University of Gdańsk,

Kładki 24 St.

80-822 Gdańsk, Poland the development of embryos in these unique carnivorous plants. We observed that in Utricularia nutritive tissue cells, actin forms a randomly arranged network of F-actin, and later in syncytium, two patterns of F-actin were observed, one characteristic for nutritive cells and second-actin bundles - characteristic for haustoria and suspensors, thus syncytia inherit their F-actin patterns from their progenitors.

Keywords Cell fusion - Endosperm haustoria - Syncytium . Embryo nutrition · Lentibulariaceae

\section{Introduction}

The syncytia formed by Utricularia, carnivorous plants which belong to the family Lentibulariaceae, Lamiales (Jobson et al. 2003; Müller et al. 2004), are extremely unusual because they arise from different progenitor cells; cells of maternal sporophytic nutritive tissue and the micropylar endosperm haustorium (both maternal and paternal genetic material). It was recently shown that these syncytia are characterized by hypertrophy of nuclei, abundant endoplasmic reticulum and organelles, and the occurrence of wall ingrowths forming an active organ which transport nutrients to the developing embryo (Płachno and Świątek 2010a. Utricularia syncytia have structural and functional similarities in common with syncytia induced by parasitic cyst nematodes (Sobczak and Golinowski 2009 and literature cited therein) including the characteristics mentioned above. In both types of syncytia, their development is accompanied by nuclear changes - hypertrophy of nuclei. In nematode-induced syncytia, endoreduplication occurs. It has been shown that a nematode modifies the plant cell cycle into a process of genome multiplication (de Almeida Engler et al. 1999; 
Goverse et al. 2000). However, these syncytia have different benefiters; in Utricularia - a new generationembryos (Fig. 1a), while in syncytia induced by parasitic cyst nematodes - nematodes which treat the host as a slave and need plant nutrients for maturation (Davis et al. 2009; Gheysen and Mitchum 2009). It would seem that syncytia that are very active in the case of physiological activity should have a well-developed actin cytoskeleton, but unexpectedly, during the development of syncytia, no filamentous actin organization was observed. There was a diffuse signal of actin, which could be the result of cytoskeleton depolymerization (de Almeida Engler et al. 2004). Because the syncytia of Utricularia have a number of aspects in common with syncytia induced by parasitic cyst
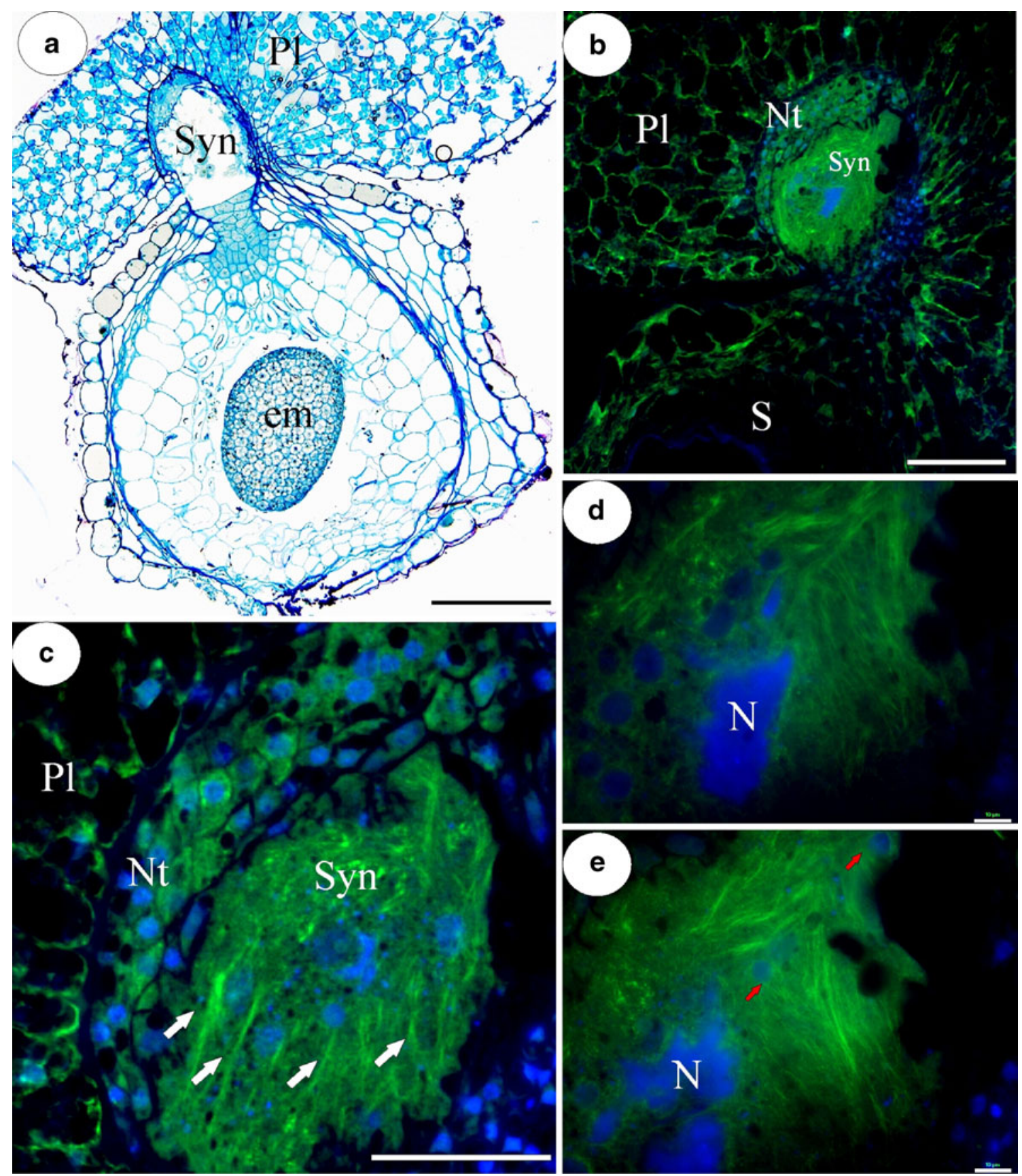

Fig. 1 a Light micrograph of section through syncytium and seed with embryo of $U$. intermedia. Syn syncytium, em embryo, $P l$ placenta; bar $=200 \mu \mathrm{m}$. b Section through syncytium and seed, note dense array of actin filaments in syncytium. Syn syncytium, $S$ seed, $N t$ nutritive tissue, $P l$ placenta; bar $=200 \mu \mathrm{m}$. c F-actin cables (arrows) running parallel to each other, across the syncytium. Syn syncytium, $N t$ nutritive tissue, $P l$ placenta; bar $=50 \mu \mathrm{m}$. d, e Two optical sections through syncytium showing giant endosperm nucleus $(N)$ and network of numerous F-actin bundles; arrows - nuclei from former nutritive tissue cells; bar $=8 \mu \mathrm{m}$ 
nematodes, we would like investigate how an actin cytoskeleton is arranged in these special syncytia.

\section{Materials and methods}

\section{Plant material}

Fruits of Utricularia intermedia Hayne (sect. Utricularia) were obtained from a locality in southern Poland: the Jeleniak-Mikuliny Nature Reserve $\left(50^{\circ} 32.554 \mathrm{~N}, 018^{\circ}\right.$ 44.146 E, 247 ma.s.1.) near the town of Lubliniec (Płachno and Świątek 2008).

\section{Immunofluorescence of microfilaments}

The placentas with ovules were fixed as described above and then used according to the procedure of Świerczyńska and Bohdanowicz (2003). After fixation and three washes in actin-stabilizing buffer (ASB), they were dehydrated in a graded ethanol series containing $10 \mathrm{mM}$ dithiothreitol. The material was then infiltrated with Steedmans's Wax. Sections $(5 \mu \mathrm{m})$ were made from the embedded ovaries and adhered to microscope slides coated with Mayer's egg albumen. The sections were dried overnight, dewaxed in ethanol, rehydrated in an ethanol-PBS series, and rinsed in ASB. After $10 \mathrm{~min}$ in methanol at $-20^{\circ} \mathrm{C}$, they were washed in ASB and then incubated in a monoclonal antibody against actin (clone C4) overnight at $4{ }^{\circ} \mathrm{C}$. Then the sections were washed in MSB and incubated for $4 \mathrm{~h}$ in secondary Alexa 488-conjugated anti-mouse antibody. The slides were rinsed in PBS, and the nuclei were stained by DAPI. The slides were then mounted in an anti-fading solution. In the control experiments, conducted in a similar manner and omitting the first antibody, no actin staining was detected. Fluorescence was examined with Nikon Eclipse E800 and Olympus BX60 epifluorescence microscopes. Chosen slides were examined using an Olympus FV1000 (Olympus, Poland) confocal system equipped with an Olympus IX81 inverted microscope (University of Silesia).

\section{Light microscope}

The placentas with ovules were fixed and then used according to the procedure of Płachno and Świątek (2009, 2010a, b).

\section{Results and discussion}

The formation and ultrastructural organization of syncytia in Utricularia have recently been described (see Płachno and Świątek 2010a). Actin microfilaments form a dense array in the entire cytoplasm of the syncytium (Fig. 1b-e). Within this actin network, thick actin cables running parallel to each other are also visible across the syncytium (Fig. 1c). The syncytial cytoplasm of the mature syncytium is stratified into two main zones - a central zone where two of the giant nuclei from the endosperm haustorium occur and a marginal zone where new protoplasts of the nutritive cells join the syncytium. Long actin bundles display a clear orientation running throughout the cytoplasm from the marginal to central part of the syncytium but also obliquely throughout the syncytium (Fig. 1d, e). Using an epifluorescence microscope, it was observed that a delicate actin meshwork invests both the giant nuclei from the endosperm haustorium and also nuclei from the nutritive tissue cells which were incorporated into the syncytium (Fig. 1d, e). When reconstructed using confocal laser scanning microscopy (CLSM), it is clear that actin filaments occur close to the nuclear envelope and also that the actin bundles penetrate the spaces between the lobes of giant nuclei from the former endosperm haustorium (Fig. 2a, b). One of these amoeboid-shaped nuclei is shown in Fig. 2a, b. It has one giant nucleolus in the central part, and moreover, smaller additional nucleoli which appear in the lobes of this nucleus. Cross-linked microfilaments form a dense actin array in the cytoplasm in this part of the syncytium. Near the giant nuclei, there are small nuclei, and their regular shape may suggest that they originate from the nutritive cells. These nuclei are also surrounded by the extensive actin cytoskeleton (Fig. 2a). In the marginal part of the syncytium, there is an extremely dense array of cross-linked actin microfilaments (Fig. 2c). An extensive network of actin microfilaments occurs in the area where the cell walls are digested and the protoplast of nutritive tissue cells fuses with the syncytium (Fig. 2c). In nutritive tissue cells, which have not yet fused with the syncytium, actin microfilaments form a randomly arranged network (Fig. 2c). In placental parenchyma cells, which border the nutritive tissue, there is delicate actin meshwork (Fig. 2c); actin microfilaments congregate around the nuclei and the amyloplast which contain a large starch grain.

We show that despite the many similarities in the ultrastructure, the syncytia of Utricularia, unlike syncytia induced by parasitic cyst nematodes, have a well-developed actin cytoskeleton. This difference may result from the specific mode of nutrition transport of parasitic nematodes. Depolymerization of actin microfilaments and also microtubules may decrease the viscosity of cytoplasm, and this may help nematodes in nutrient absorption (de Almeida Engler et al. 2004). A well-developed F-actin cytoskeleton, like in Utricularia, was also described in the endosperm in the micropylar endosperm chamber of Coronopus didymus (Brassicaceae) (Nguyen et al. 2002) and in the 

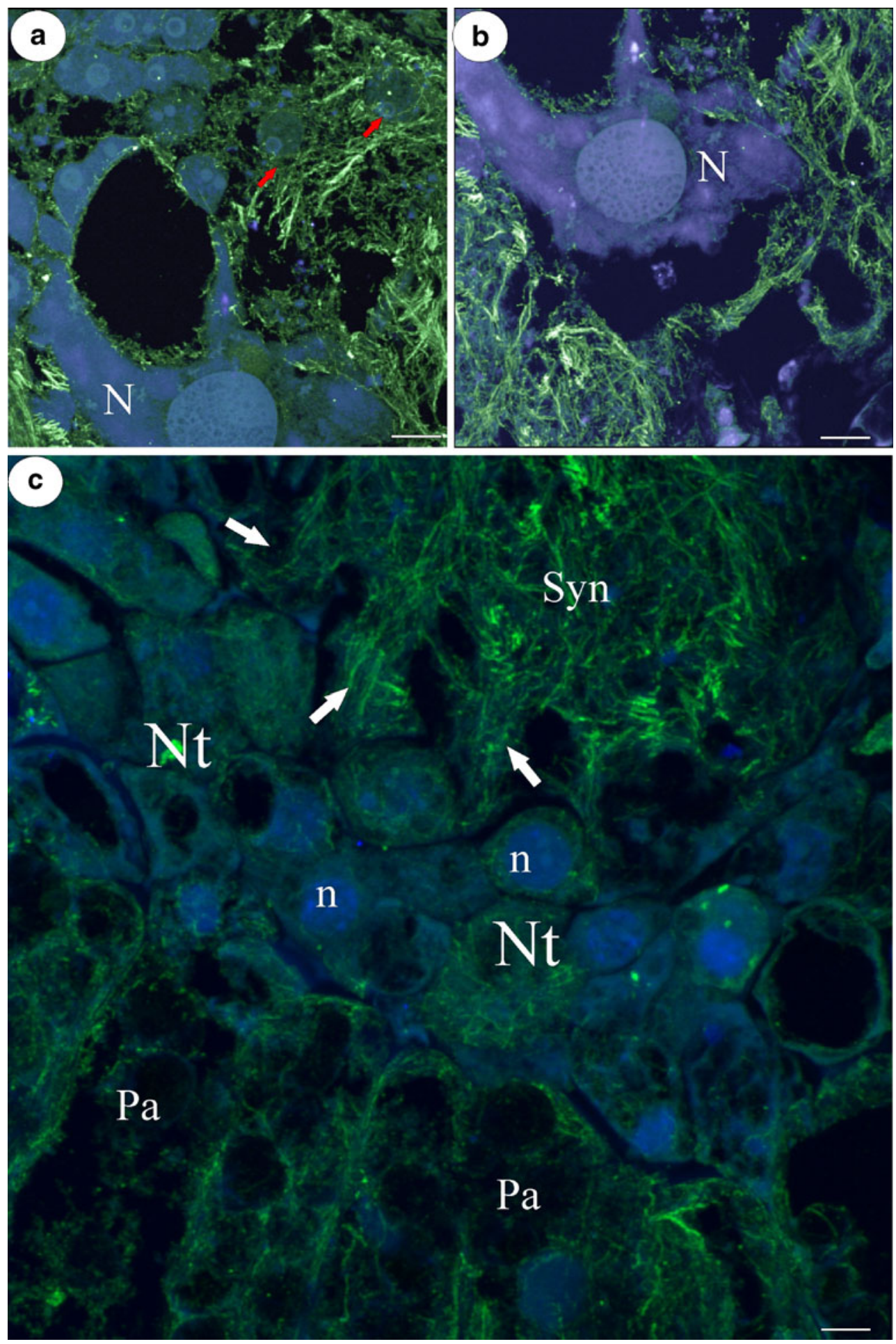

Fig. 2 a, b CLSM reconstruction of central part of the syncytium, note amoeboid in shape giant nucleus $(N)$ with large nucleous; arrows - nuclei from former nutritive tissue cells; $b a r=10 \mu \mathrm{m}$. c Marginal part of the syncytium - an extensive network of actin microfilaments

endosperm chalazal haustorium of Rhinanthus serotinus (Orobanchaceae) (Świerczyńska and Bohdanowicz 2003). In both cases, these structures play a nutritive role in relation to the developing embryo, thus they behave exactly occurs in place where cell walls are digested and protoplast of nutritive tissue cells fusing with syncytium (arrows). Nt nutritive tissue cells, $n$ nucleus of nutritive tissue cell, Syn syncytium, $P a$ placental parenchyma cell; bar $=4 \mu \mathrm{m}$

like the syncytia in Utricularia. The long actin cables and bundles of F-actin, which run across the syncytium, probably form the transport routes for macromolecules and organelles; especially since F-actin is involved in the 
intracellular transport of organelles, auxin transport, and since it also regulates vacuolar structures and dynamics (e.g., Boevink et al. 1998; Dhonukshe et al. 2008; Nick 1999; Collings et al. 2002; Higaki et al. 2006; Kadota et al. 2009). In the Utricularia syncytia, the actin bundles are associated with mitochondria and endoplasmic reticulum; it should be underlined that the syncytium cytoplasm is rich in both of these organelles (Płachno and Światek 2010a, b), and it seems that actin bundles have fundamental role in the movement of these organelles inside such a large structure as syncytium. The endoplasmic reticulum is the largest reservoir of cellular membranes in eukaryotic cells. During formation of the syncytia, there are dynamic cell membrane changes due to progressive cell mergers. Recently, the participation of the F-actin cytoskeleton in fast endoplasmic reticulum motility has been well documented using a velocity-distribution map for the GFP-labeled endoplasmic reticulum in Arabidopsis (Ueda et al. 2010).

The well-developed cytoskeleton in syncytia is probably also connected with the unique and complex development of these syncytia because an extensive network of F-actin occurs in the area where cell walls are digested and the protoplast of nutritive tissue cells fuses with the syncytium. In plant cells, F-actin is responsible for proper cell wall dynamic (cell wall growth and expansion, Staiger et al. 2000), e.g., transport of cell wall pectins is F-actin dependent (Baluška et al. 2002). We think that F-actin is also connected with remodeling of cell walls in the syncytia. There are two opposing processes related to the dynamics of the cell wall which occur in the syncytium; the first is digestion of cell walls of the nutritive tissue cells, which fuse with the syncytium, the second-formation of the cell wall ingrowths on the cell wall surface in the some marginal parts of the syncytium (Płachno and Światek 2010a), thus F-actin is involved here in both cell wall dissolution and deposition. In the places where wall ingrowths occur, there is an intensive selective transport over short distance (transfer cells; Gunning and Pate 1969; 1974; Offler et al. 2003), in which F-actin also takes part.

It is known that F-actin is responsible for the movement and position of cell nuclei (Ketelaar et al. 2002; Chytilova et al. 2000). In Utricularia syncytia, the giant endosperm nuclei move until they finally occupy a more or less central position within the syncytium (Fig. 3 in Płachno and Światek 2010a). The nuclei from the former nutritive tissue cells also change their position within the syncytium. The motility of nuclei in the syncytium is another reason for the presence bundles of actin in the syncytium cytoplasm. The giant nuclei also changes shape forming lobes; actin may be responsible for this especially since recently it has been proved that the perinuclear actin cap regulates the nuclear shape in animal cells (Khatau et al. 2009). Actin is encoded by large gene families in plants; numbers of family member vary from 10 in Arabidopsis to more than 100 in Petunia (Baird and Meagher 1987; McDowell et al. 1996). So there are several actin isoform which occur in the different tissues and time during plant development (Meagher et al. 1999). In Arabidopsis, there occur two classes of actin isoform, which are preferentially expressed in either generative or vegetative organs (McDowell et al. 1996; Kandasamy et al. 2002). In connection with this knowledge, the important questions should be asked. Utricularia syncytia arise from different progenitor cells; cells of maternal sporophytic nutritive tissue and the micropylar endosperm haustorium. Are different isoforms of actin present in the two kinds of cells and what happened after cells' fusing? Are there different actin-binding proteins from these two kinds of cells that can interact in the merged cytoplasm in some unique way? Unfortunately, there is now a lack of knowledge about isoforms of actin in Utricularia. However, Lentibulariaceae to which Utricularia genus belongs, are anomalous plants in various subjects (Albert et al. 2010), e.g., specific body plan (Rutishauser and Isler 2001), embryo reduction (Płachno and Świątek 2010b), variation in genome size from approximately 60 to $1,500 \mathrm{Mb}$ (Greilhuber et al. 2006), and an adaptive changes in cytochrome $\mathrm{C}$ oxidase, which provide respiratory power (Laakkonen et al. 2006). Therefore, it can be assumed that the Utricularia will be also characterized by the unusuality in terms of actin and proteins associated with it. In case of Utricularia syncytia, results of Binarova et al. 1996 and Schwarzerova et al. 2010 who described that in spruce, meristematic cells contain a distinctly different F-actin pattern (dense, randomly oriented actin filaments) than suspensor cells (thick actin cables oriented longitudinally and transversely oriented thinner actin filaments) should be mentioned, and this is connected with different expression of actin isoforms. Protoplasts which arise from these different classes of cells have F-actin distribution in their cells of origin. The actin pattern with thick actin cables oriented longitudinally, occur also in large highly vacuolated and polyploid cells of angiosperms such as endosperm haustoria (Świerczyńska and Bohdanowicz 2003) and embryo suspensor (Kozieradzka-Kiszkurno et al. 2006). We observed that in Utricularia nutritive tissue cells, actin forms a randomly arranged network of F-actin, and later in syncytium, two patterns of F-actin were observed, one characteristic for nutritive cells and second-actin bundles - characteristic for haustoria and suspensors, thus syncytia inherit their F-actin patterns from their progenitors.

In conclusion, an explanation for the presence of an extensive F-actin network in the Utricularia syncytia is probably connected with the movement of nuclei and other organelles and also the transport of nutrients in these physiological activity organs which are necessary for the development of embryos in these unique carnivorous plants. 
Acknowledgments This study was funded by grant N N304 002536 from the Polish Ministry of Science and Higher Education. The first author gratefully acknowledges the support of an award from the Foundation for Polish Sciences (Start Programme). We especially thank both Małgorzata Ignatowska (University of Gdańsk) and Hanna Sas-Nowosielska (University of Silesia) for their expert technical help.

Conflict of interest statement The authors declare that they have no conflict of interest.

Open Access This article is distributed under the terms of the Creative Commons Attribution Noncommercial License which permits any noncommercial use, distribution, and reproduction in any medium, provided the original author(s) and source are credited.

\section{References}

Albert VA, Jobson RW, Michael TP, Taylor DJ (2010) The carnivorous bladderwort (Utricularia, Lentibulariaceae): a system inflates. J Exp Bot 61:5-9. doi:10.1093/jxb/erp349

Baird WV, Meagher RB (1987) A complex gene superfamily encodes actin in Petunia. EMBO J 6:3223-3231

Baluška F, Hlavacka A, Šamaj J, Palme K, Robinson DG, Matoh T, McCurdy DW, Menzel D, Volkmann D (2002) F-actin-dependent endocytosis of cell wall pectins in meristematic root cells: insights from brefeldin A-induced compartments. Plant Physiol 130:422-443

Binarova P, Cihalikova C, Doležel J, Gilmer S, Fowke LC (1996) Actin distribution in somatic embryos and embryogenic protoplasts of white spruce (Picea glauca). In Vitro Cell Dev Biol Plant 32:59-65

Boevink P, Oparka K, Santa Cruz S, Martin B, Betteridge A, Hawes C (1998) Stacks on tracks: the plant Golgi apparatus traffics on an actin/ER network. Plant J 15:441-447

Chytilova E, Macas J, Sliwińska E, Rafelski SM, Lambert GM, Galbraith DW (2000) Nuclear dynamics in Arabidopsis thaliana. MBoC 11:2733-2741

Collings DA, Harper JDI, Marc J, Overall RL, Mullen RT (2002) Life in the fast lane: actin-based motility of plant peroxisomes. Can J Bot 80:430-441

Davis EL, Hussey RS, Baum TJ (2009) Parasitism genes: what they reveal about parasitism. In: Berg RH, Taylor CG (eds) Cell biology of plant nematode parasitism. Plant cell monographs 15 . Springer, Heidelberg, pp 15-44

de Almeida Engler J, De Vleesschauwer V, Burssens S, Celenza JL, Inzé D, Van Montagu M, Engler G, Gheysen G (1999) Molecular markers and cell cycle inhibitors show the importance of the cell cycle progression in nematode-induced galls and syncytia. Plant Cell 11:793-807

de Almeida Engler J, Van Poucke K, Karimi M, De Groodt R, Gheysen G, Engler G, Gheysen G (2004) Dynamic cytoskeleton rearrangements in giant cells and syncytia of nematode infected roots. Plant J 38:12-26

Dhonukshe P, Grigorieve I, Fischer R et al (2008) Auxin transport inhibitors impair vesicle motility and actin cytoskeleton dynamics in diverse eukaryotes. PNAS 105:4489-4494

Gheysen G, Mitchum MG (2009) Molecular insights in the susceptible plant response to nematode infection. In: Berg RH, Taylor CG (eds) Cell biology of plant nematode parasitism. Plant cell monographs 15. Springer, Berlin, pp 45-81

Goverse AJ, de Engler AJ, Verhees J, van der Krol S, Helder HH, Gheysen G (2000) Cell cycle activation by plant parasitic nematodes. Plant Mol Biol 43:747-761
Greilhuber J, Borsch T, Müller K, Worberg A, Porembski S, Barthlott W (2006) Smallest angiosperm genomes found in Lentibulariaceae, with chromosomes of bacterial size. Plant Biol 8:770-777. doi:10.1055/s-2006-924101

Gunning BES, Pate JS (1969) "Transfer cells" plant cells with wall ingrowths, specialized in relation to short distance transport of solutes - their occurrence, structure, and development. Protoplasma 68:107-133

Gunning BES, Pate JS (1974) Transfer cells. In: Robards AW (ed) Dynamic aspects of plant ultrastructure. McGraw-Hill, London, pp $441-480$

Higaki T, Kutsuna N, Okubo E, Sano T, Hasezawa S (2006) Actin microfilaments regulate vacuolar structures and dynamics: dual observation of actin microfilaments and vacuolar membrane in living tobacco BY-2 cells. Plant Cell Physiol 47:839_ 852

Jobson RW, Playford J, Cameron KM, Albert VA (2003) Molecular phylogenetics of Lentibulariaceae inferred from plastid rps16 intron and trnL-F DNA sequences: implications for character evolution and biogeography. Syst Bot 28:157-171

Kadota A, Yamada N, Suetsugu N, Hirose M, Saito C, Shoda K, Ichikawa S, Kagawa T, Nakano A, Wada M (2009) Short actinbased mechanism for light-directed chloroplast movement in Arabidopsis. PNAS 106:13106-13111

Kandasamy MK, McKinney EC, Meagher RB (2002) Functional nonequivalency of actin isovariants in Arabidopsis. Mol Biol Cell 13:251-261

Ketelaar T, Faivre-Moskalenko C, Esseling JJ, de Ruijter NCA, Grierson CS, Dogterom M, Emons AMC (2002) Positioning of nuclei in Arabidopsis root hairs: an actin-regulated process of tip growth. Plant Cell 14:2941-2955

Khatau SB, Hale CM, Stewart-Hutchinson PJ, Patel MS, Stewart CL, Searson PC, Hodzic D, Wirtz D (2009) A perinuclear actin cap regulates nuclear shape. PNAS 106:19017-19022

Kozieradzka-Kiszkurno M, Świerczyńska J, Bohdanowicz J (2006) The actin filaments of the embryo-suspensor in Sedum acre L. Acta Biol Cracov Ser Bot 48(suppl 1):57

Laakkonen L, Jobson RW, Albert VA (2006) A new model for the evolution of carnivory in the bladderwort plant (Utricularia): adaptive changes in cytochrome c oxidase (COX) provide respiratory power. Plant Biol 8:758-764. doi:10.1055/s-2006924459

McDowell JM, Huang SR, McKinney EC, An YQ, Meagher RB (1996) Structure and evolution of the actin gene family in Arabidopsis thaliana. Genetics 142:587-602

Meagher RB, McKinney EC, Kandasamyh MK (1999) Isovariant dynamics expand and buffer the responses of complex systems: the diverse plant actin gene family. Plant Cell 11:995-1006

Müller K, Borsch T, Legendre L, Porembski S, Theisen I, Barthlott W (2004) Evolution of carnivory in Lentibulariaceae and the Lamiales. Plant Biol 6:477-490

Nguyen H, Brown RC, Lemmon BE (2002) Cytoskeletal organization of the micropylar endosperm in Coronopus didymus L. (Brassicaceae). Protoplasma 219:210-220

Nick P (1999) Signals, motors, morphogenesis - the cytoskeleton in plant development. Plant Biol 1:169-179

Offler CE, McCurdy DW, Patrick JW, Talbot MJ (2003) Transfer cells: cells specialized for a special purpose. Annu Rev Plant Biol 54:431-454

Płachno BJ, Świątek P (2008) Cytoarchitecture of Utricularia nutritive tissue. Protoplasma 234:25-32. doi:10.1007/s00709008-0020-9

Płachno BJ, Światek P (2009) Functional anatomy of the ovule in Genlisea with remarks on ovule evolution in Lentibulariaceae. Protoplasma 236:39-48. doi:10.1007/s00709-009-0045-8 
Płachno BJ, Świątek P (2010a) Syncytia in plants: cell fusion in endosperm - placental syncytium formation in Utricularia (Lentibulariaceae). Protoplasma. doi:10.1007/s00709-010-0173-1

Płachno BJ, Świątek P (2010b) Unusual embryo structure in viviparous Utricularia nelumbifolia, with remarks on embryo evolution in genus Utricularia. Protoplasma 239:69-80. doi:10.1007/s00709-009-0084-1

Rutishauser R, Isler B (2001) Developmental genetics and morphological evolution of flowering plants, especially bladderworts (Utricularia): Fuzzy Arberian Morphology complements classical morphology. Ann Bot 88:1173-1202

Schwarzerova $\mathrm{K}$ et al (2010) The role of actin isoforms in somatic embryogenesis in Norway spruce. BMC Plant Biol 10:89. doi:10.1186/1471-2229-10-89
Sobczak M, Golinowski W (2009) Structure of cyst nematode feeding sites. In: Berg RH, Taylor CG (eds) Cell biology of plant nematode parasitism. Plant cell monographs 15. Springer, Berlin, pp 153-187

Staiger CJ, Baluška F, Volkmann D, Barlow P (2000) Actin: a dynamic framework for multiple plant cell functions. Springer, Dordrecht

Świerczyńska J, Bohdanowicz J (2003) Microfilament cytoskeleton of endosperm chalazal haustorium of Rhinanthus serotinus (Scrophulariaceae). Acta Biol Cracov Ser Bot 45:143-148

Ueda H, Yokota E, Kutsuna N, Shimada T, Tamura K, Shimmen T, Hasezawa S, Dolja VV, Hara-Nishimura I (2010) Myosindependent endoplasmic reticulum motility and F-actin organization in plant cells. PNAS 107:6894-6899 